\title{
Impact of Climate Change on River Discharge and Rainfall Pattern: A Case Study from Marshyangdi River basin, Nepal
}

\author{
Achut Parajulii ${ }^{1,2,}$ Lochan Prasad Devkota $^{3}$, Tirtha Raj Adhikarii ${ }^{3}$, Susmita Dhakal ${ }^{1}$, \\ Rijan Bhakta Kayastha ${ }^{2}$ \\ ${ }^{1}$ Central Department of Environmental Science, Tribhuvan University \\ ${ }^{2}$ Himalayan Cryosphere Climate and Disaster Research Center, Kathmandu University \\ ${ }^{3}$ Central Department of Hydrology \& Meteorology, Tribhuvan University
}

\begin{abstract}
Climate models have predicted increase in monsoon precipitation for Nepal and expected to enhance further in scenario of deforestation and global green house gas emission which induces extremes resulting risk of flood, landslide during monsoon while water shortage in dry season. In this study, the impact of climate change on water resource for glacierized Marshyangdi River is evaluated using HBV light hydrological model with available hydrological data (1988-2009) to predict the future water availability and change in rainfall pattern based on available rainfall data (1981-2009). The results for Marshyangdi basin with $4104.59 \mathrm{~km} 2$ area with average discharge of $204.03 \mathrm{~m}^{3} / \mathrm{s}$ (1988-2009) suggested decrease in rainy days while increase in frequency of intense rainfall, and the projected rainfall based on downscaling showed increase in rainfall for 2050 's. The model performance is adequate and able to simulate accurate result with estimated average discharge of $224.82 \mathrm{~m}^{3} / \mathrm{s}$ (1988-2009). The simulated result provided good fit with model efficiency 0.86 for first calibration and 0.81 for second calibration, while total volume difference of $1.43 \%$ and Nash-Sutcliffe Efficiency of 0.80 between observed and simulated discharge.
\end{abstract}

Keywords: Climate Change, Marshyangdi basin, HBV Light, Nepal Himalaya

\section{INTRODUCTION}

Climate Change has enormous effect on hydrology and hydrological cycle and poses challenge on future water availability. Circulation and distribution of available water under climate projection has become more complex (Pachauri, 1992; Chun, 2010). Scientific community believes that climate change will result in change of the global hydrological cycle inducing higher occurrence of extremes (Hisdal et al., 2001).
Huge fluctuation in runoff in Nepal $\left(400 \mathrm{~m}^{3} / \mathrm{s}\right.$ in February to $4300 \mathrm{~m}^{3} / \mathrm{sec}$ in August for Sapta Koshi) from season to season (Alam and Regmi, 2004) induces risks of flooding; landslide and sedimentation due to intense precipitation in monsoon and water shortage in dry season (Sharma and Shakya, 2006). The monsoon precipitation is expected to be enhanced further in a scenario of deforestation because of drier soil conditions before the onset of monsoon (Meehl, 1994). Climate models predicted 
increase in precipitation over Nepal though long-term precipitation record is unavailable (Shrestha et al., 2011). Kumar et al. (2006) suggested decrease in monsoon in northern part while increase in southern part with average $3.5^{\circ} \mathrm{C}-4^{\circ} \mathrm{C}$ based on regional climate model PRECIS (HadRM3). Different studies carried out in Himalaya suggested the increase in precipitation with changing climate (Kripalani et al., 1996; Sharma et al., 2000; Shrestha et al., 2000). The regional hydrology is extremely sensitive to small changes and may lead disorder in whole hydrological equilibrium (Alam, 2011) in light of changing rainfall pattern predicted by different climatic models (Akthar et al., 2008).

Glacier melt-water plays important role in water resources of Nepal as these resources are utilized in various purposes such as hydropower production, irrigation and water supply. The snow and glacier dominated stream contributes as reservoir which stores the water and release them as discharge, and significantly affecting the hydrological characteristics of the stream. (Jansson et al., 2003). Global rise in temperature hugely influence glacerized catchment due to acceleration in melt (Akthar et. al., 2008; Mingjie et. al., 2013) as a result the Himalayan region presents a huge threat for future water availability (Akthar et al., 2008; Immerzeel et al., 2010; Bolch et. al., 2012). Different glaciological studies have revealed the rapid mass loss in Himalayan glacier (Yamada et al., 1992; Fujita et al., 1998). The widespread glacial retreat in Nepal can have two direct consequences: 1) changes in the hydrological regime and 2) glacial lake outburst floods (MoEST, 2010).

The runoff generated from the glacierized stream can be estimated if sufficient data is available (Hagg et. al., 2008) but the remoteness, irregular monitoring and less data availability create substantial difficulties in accurate estimation of melt water discharge (Kayastha et al., 2000) especially in Himalaya. In places where data availability is the major issue the use of modelling approach serves best (Sivapalan et al., 2003). Meteorological and hydrological data derived from global and regional climate models are possibility for use in modeling extreme hydrological situations both in temporal and spatial scale (Grotch and MacCracken, 1991;Horton et al., 2006) but these processes have dynamic and complex structure therefore should be modeled as linear or nonlinear is still a doubt (Modarres and Quarda, 2013).

The reliability of hydrological catchment models is highly dependent on the calibration procedure, which is normally the search for one optimal parameter set (Jakeman and Hornberger, 1993) that governs the validation of the hydrological model. The parameter uncertainty may arise from different aspects of the modeling (Sibert, 1997), since selection of different parameters in cloud can provide good fits (Duan et al., 1992) but errors in both model structure and measured data with choice of optimal parameter itself is not reasonable (Beven and Binley, 1992).

This paper aims to investigate the impact of changing climate from 1988 to 2009 based on available meteorological data and predict the future impact on water resources i.e. 2050's using the HBV light hydrological model, Statistical Downscaling Model (SDSM) and Department of Hydrology and Meteorology (DHM data portal) for glacierized Marshyangdi basin.

\subsection{Study Area}

Marshyangdi River basin lies in the western part of Nepal that covers four district of Nepal viz. Manang, Lamjung, Gorkha and Tanahau 


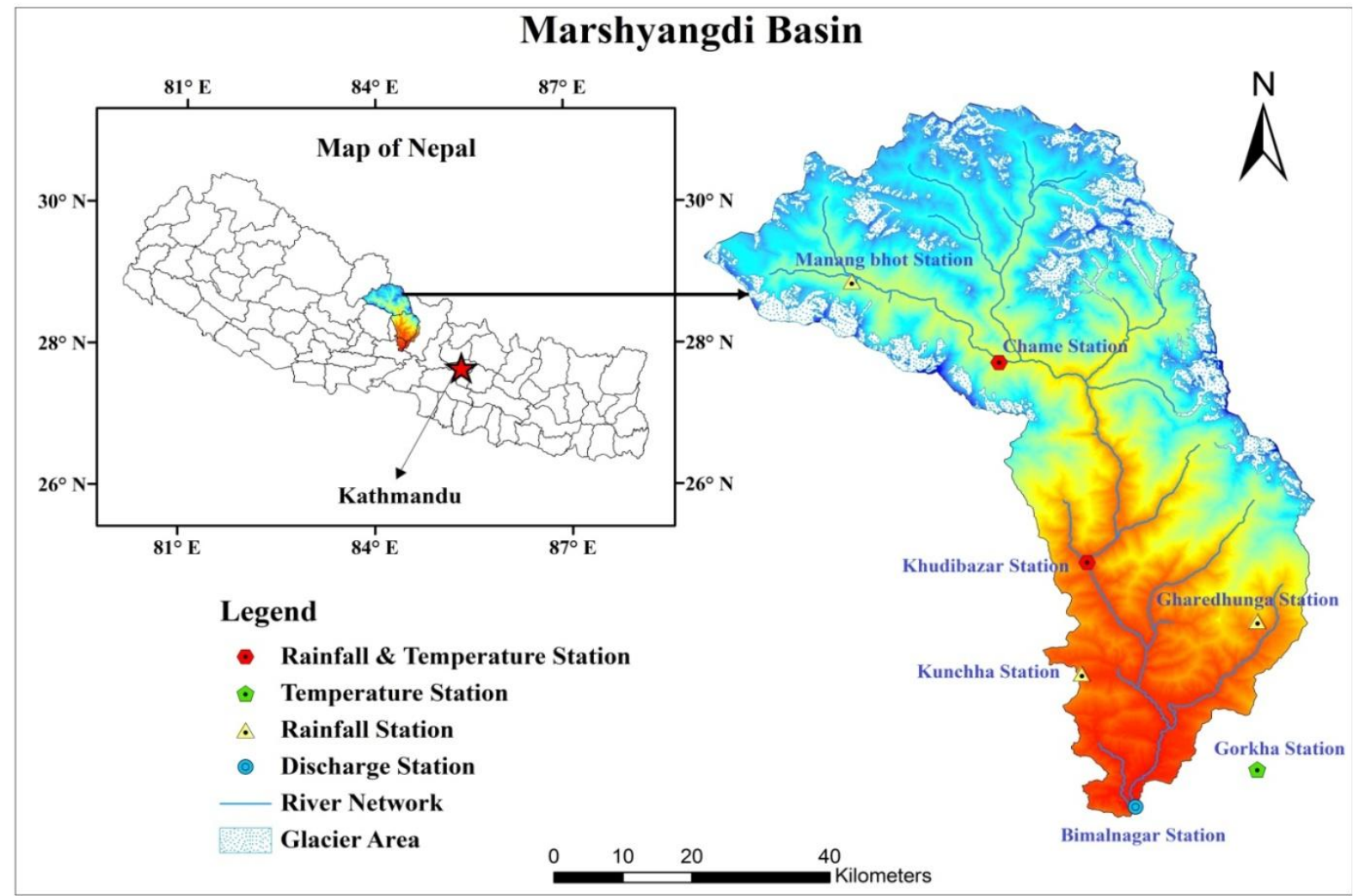

Figure 1: Study area including the hydro-meteorological station.

and drains through the northern slope of the Annapurna Mountain (Figure 1). Marshyangdi River covers basin area of $4104.59 \mathrm{~km} 2$ and the elevation ranges from (318- 8124 m.a.s.1.) with most of the area between (4000-6000 m.a.s.1.)

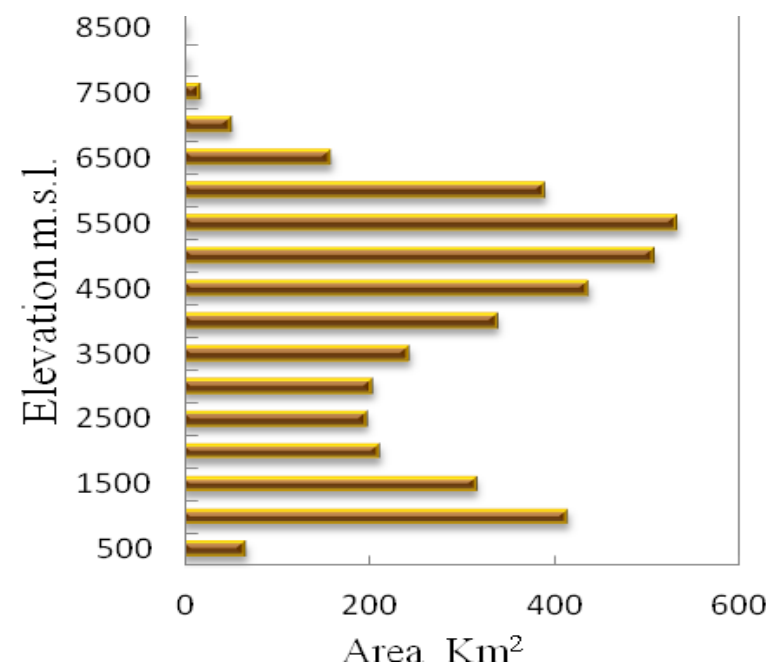

Figure 2: Hypsographic elevation of study area. as shown in Figure (2). The climate of this area ranges from cold high alpine type to hot and humid tropical type. The mean slope of this basin is $29.42^{\circ}$, which reflects the high potential relief energy of the catchment. Glacier area in

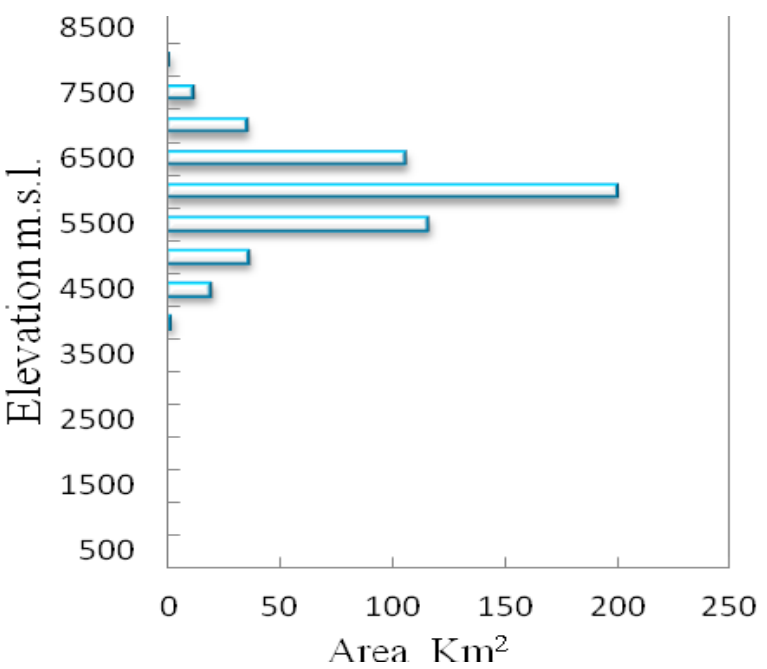


this basin covers area of $508 \mathrm{~km} 2$ which ranges from (3669-7582 m.a.s.1.) within which most of the area lies from (5500-6500 m.a.s.1.) Figure (2) that demonstrate the study area.

\section{MODEL USED AND METHOD APPLIED}

HBV Light corresponds HBV-6 described by Bergström (1992) is a conceptual model which uses daily temperature, rainfall, potential evaporation to simulate daily discharge (Seibert and Beven, 2009). The available temperature and rainfall data (1988-2009) form Department of Hydrology and Meteorology (DHM) are the calibration data containing numerous missing information and created difficulty in running the hydrological model. Statistical Downscaling
Model (SDSM 4.2) developed by Wilby and Dawson (2007) using GCM predictor for filling up the missing temperature and rainfall data in order to run the hydrological model. The mean monthly potential evaporation obtained by modified Hargreaves method (Sperna Weiland et al., 2012) after the missing meteorological data if filled. Use of downscaling approach to predict the temperature and precipitation for future 2050's and prepare necessary input to predict the future water availability is carried out. Catchment information is extracted from ASTER Digital Elevation Model (DEM), which is processed by ArcGIS 9.3 for extracting aspect and elevation (Figure 3 ) and combining aspect and elevation.

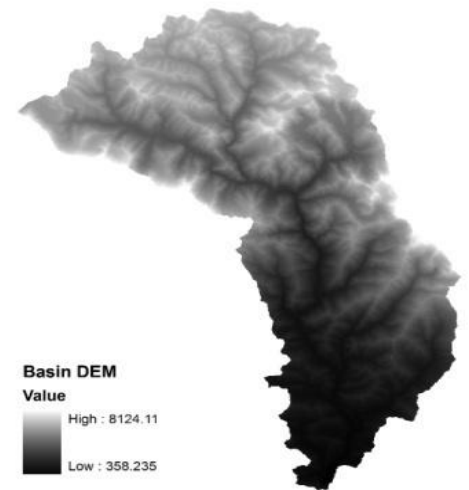

A)

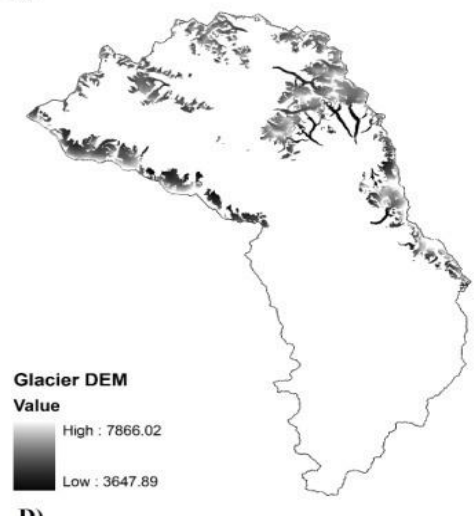

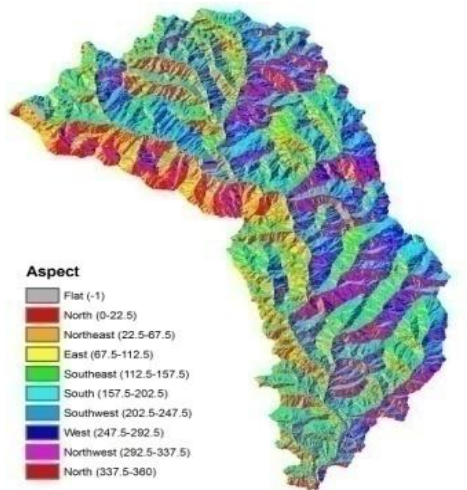

B)

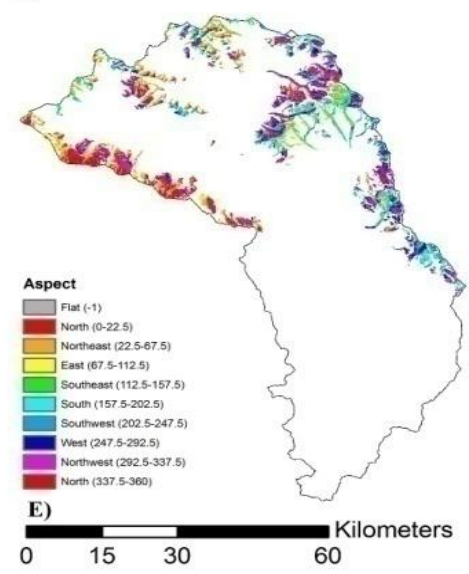

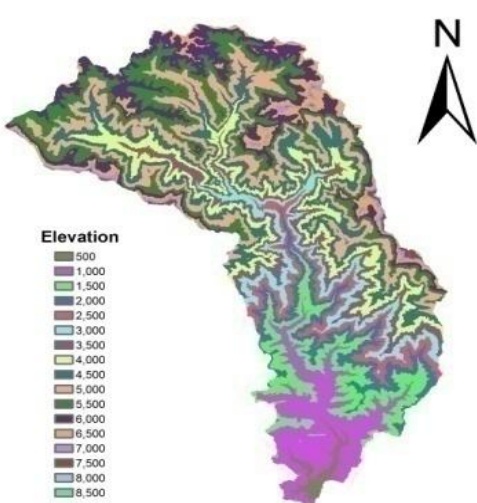

C)

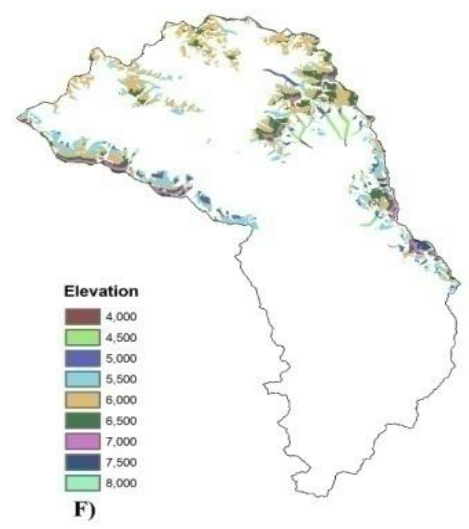

Figure 3: Different method used in processing of Marshyangdi basin data using ArcGIS a) DEM of basin b) Aspect map of basin c) Elevation map of basin d) DEM masked from glacier outline e) Aspect derived from masked DEM of glacier f) Elevation map from masked DEM of glacier. 
Glacier data is provided by ICIMOD which is masked with ASTER DEM and similar procedure is adopted for combining aspect and elevation (Figure 3). Seventeen elevation zones are generated from the available data by the reclassification process. Finally combined aspect-elevation map is divided into three parts viz. North, South and East/West.

The data available from DHM data portal is also used for impact on rainfall in future. Calibration of the model is carried by using GAP optimization tool (Genetic Algorithm and Powell), the genetic algorithm starts with one or more populations of 50 randomly generated parameter sets that are located within the given ranges. These sets are being evaluated by running the model and thus the goodness of fit of each set is determined by the value of the employed objective function. Parameter sets with a good value are given a higher probability to generate new sets than those sets that gave poorer results (Seibert, 2000). Different parameters used in calibration of model are stated below.

Where, TT is the threshold temperature $\left({ }^{\mathrm{O}} \mathrm{C}\right)$, CFMAX is the degree day factor $\left(\mathrm{mm}^{\mathrm{O}} \mathrm{C}^{-1} \mathrm{~d}^{-1}\right)$, SFCF is the snow fall correction factor, CFR is the refreezing coefficient, $\mathrm{CWH}$ is the water holding capacity, FC is the field capacity ( $\mathrm{mm})$,
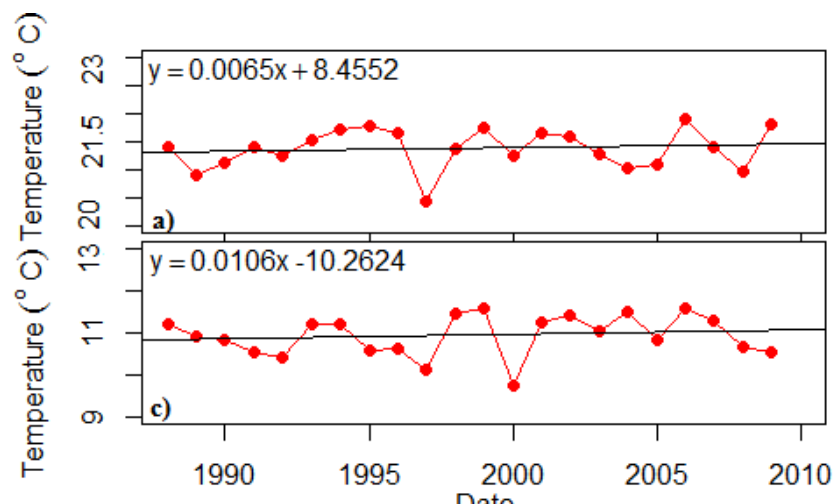
Date
LP is the threshold for reduction of evaporation, BETA is the shape coefficient, $\mathrm{K}_{0}, \mathrm{~K}_{1}$ and $\mathrm{K}_{2}$ are recession coefficient for upper zone, middle zone and lower zone $\left(\mathrm{d}^{-1}\right)$ respectively, PERC is the percolation from upper to lower zone $\left(\mathrm{mm} \mathrm{d}^{-1}\right)$, UZL is the upper zone threshold (mm), MAXBAS is the triangular weighting function (d), CET is the other routing function (d), PCALT is the precipitation gradient (\% 100 $\left.\mathrm{m}^{-1}\right)$, TCALT is temperature gradient $\left({ }^{\circ} \mathrm{C} 100\right.$ $\left.\mathrm{m}^{-1}\right)$, PELEV is mean elevation of precipitation station $(\mathrm{m})$ and TELEV is the mean elevation of temperature station $(\mathrm{m})$.

Two calibration and two validation period is taken in the study due to missing discharge data. The first calibration period is taken from year 1988-1994 while first validation period from 1995-2001 while the second calibration period started from 2002 -2005 with validation period from 2006-2009.

In order to make agreement between observed discharge and simulated discharge (Nash and Sutcliffe, 1970) method was applied and to give more weight on low flow Nash-Sutcliffe efficiency based on the logarithm of observed and simulated discharge was used as described by (Seibert, 2005). Also the volume error (VE) and the coefficient of determinant are used to test the goodness of fit.

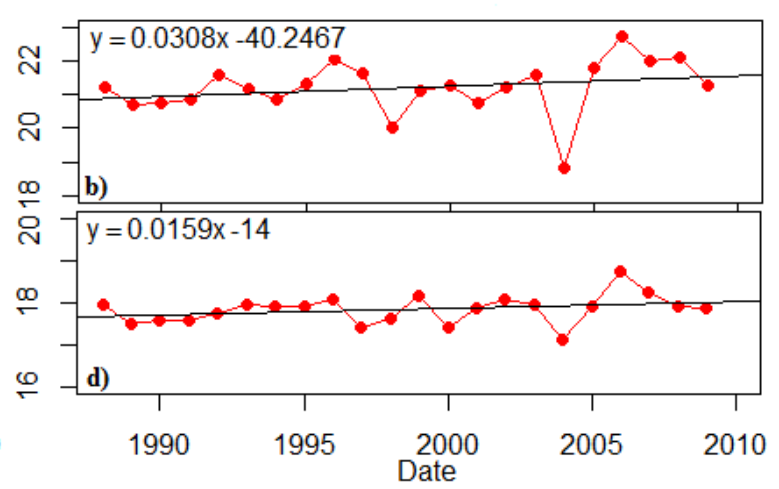

Figure 4: Annual average temperature within study area a) Annual average temperature of Khudibazar station b) Annual average temperature for Gorkha station c) Annual average tempeature for Chame station d) All station average annual temperature. 


\section{RESULT AND DISCUSSION}

The linear temperature trend (1988-2009) suggested the increase in temperature within Marshyangdi basin. Overall all the available station within study basin suggested slight increase $\left(0.0159{ }^{\circ} \mathrm{C} /\right.$ year $)$ in temperature (Figure 4).

Although, it will be too soon to say there is climate change but linear trend suggested slight increase in temperature over study area. Among the three stations within the station highest increase is observed in Gorkha station while lowest in Khudibazar station.

There are five rainfall stations available within study having different type of climate, within which the station located at Manang district i.e. Chame and Manang Bhot station which receives significantly less rainfall compared to station located at Lamjung station i.e. Khudibazar, Kunchha station and Gharedhunga station (Figure 5). Although the projection of the climatic model suggested the increase in
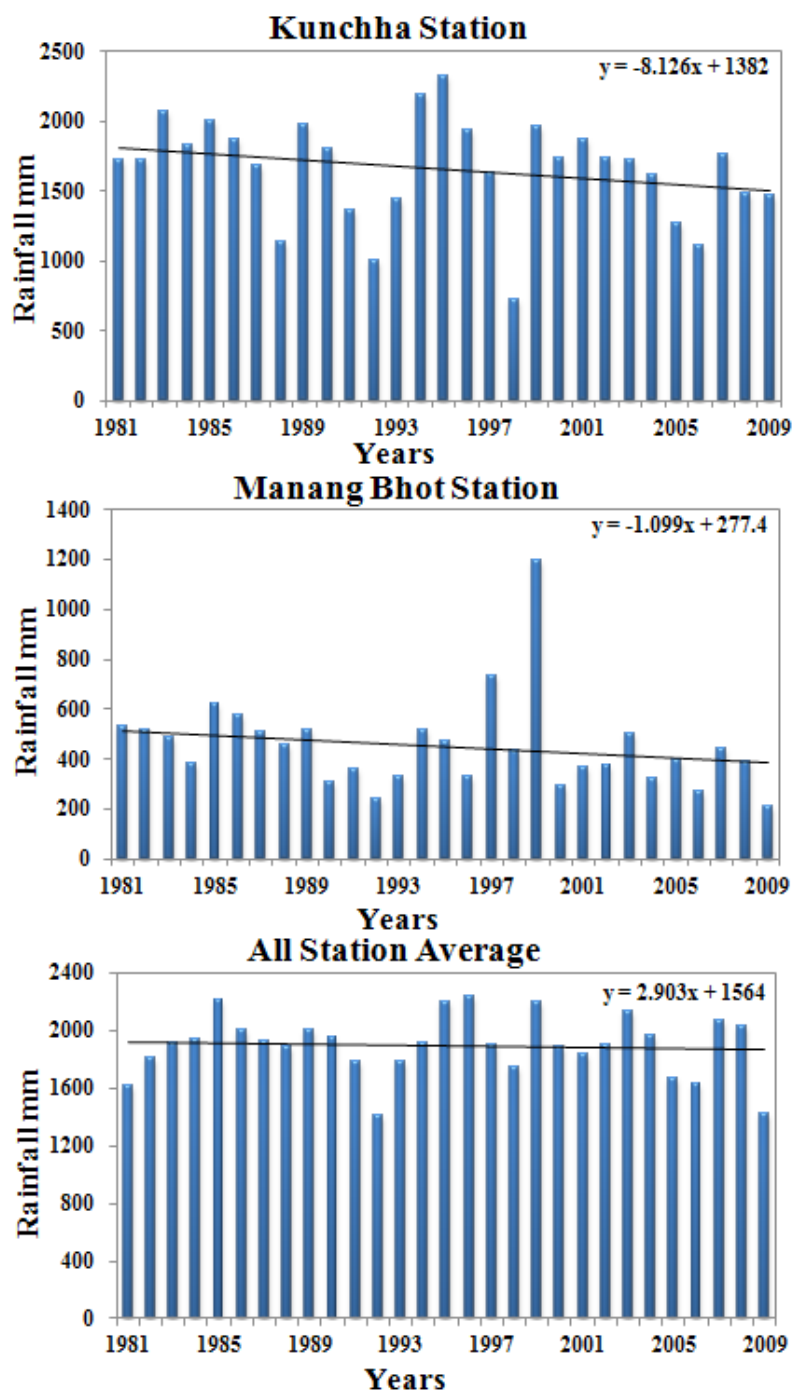

Figure 5: Annual total rainfall within the Marshyangdi basin. 


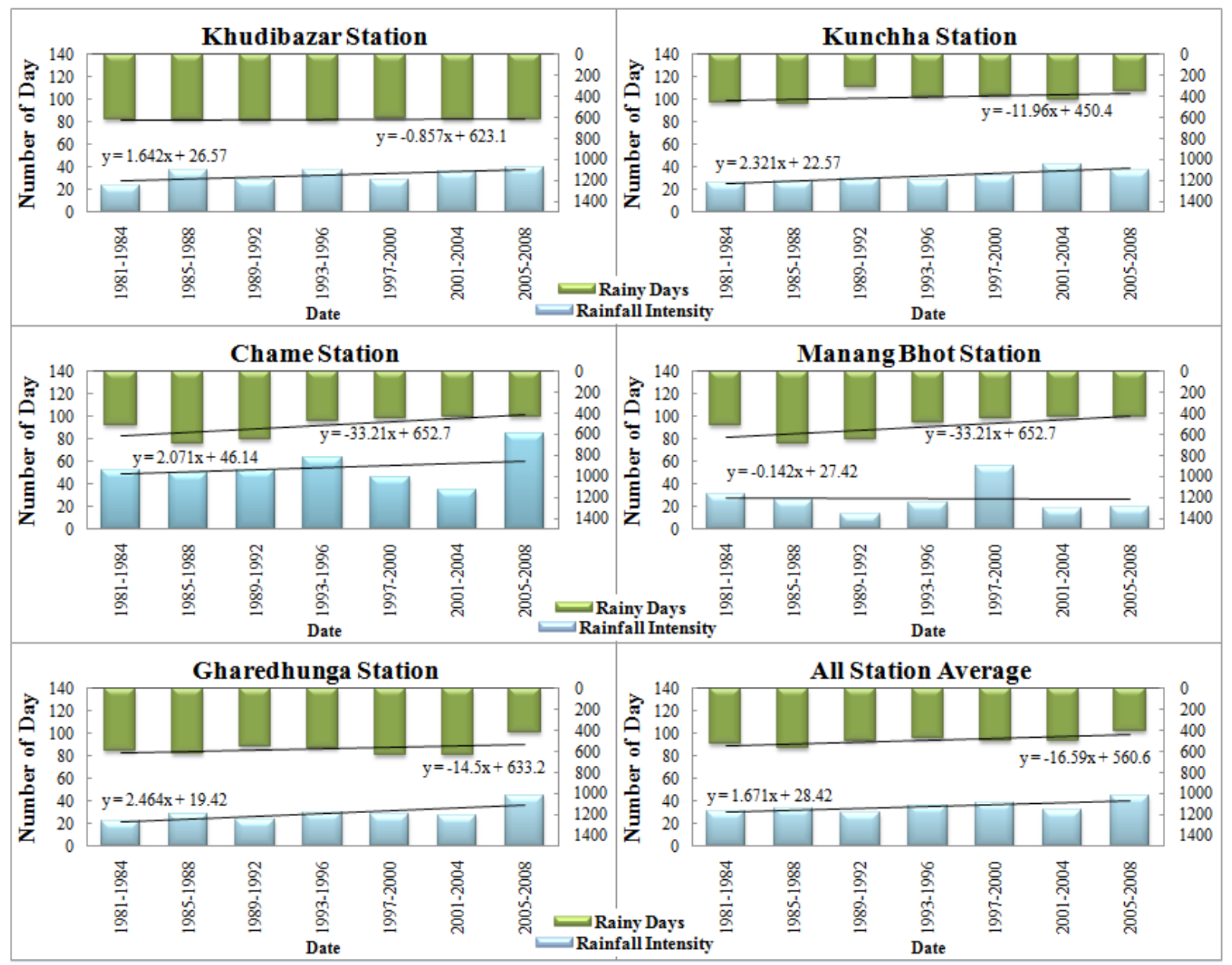

Figure 6: Number of rainy days within four consecutive years and Number of days with intense rainfall.

rainfall within Nepal but the linear trend (19812009) suggests the slight increase in rainfall for all station average rainfall $(2.9 \mathrm{~mm} /$ year$)$.

The rainfall pattern is different in all five stations within the study area. In some stations there is increasing linear trend while in some there is decline in rainfall amount. The rainfall is the dominant source for water discharge in the basin and fluctuation in rainfall creates the fluctuation in river discharge. In order to investigate change in rainfall pattern within study total number of rainy days analysis is carried out. The result suggested the decrease in number of rainy days for all station available.
The $70 \mathrm{~mm}$ threshold rainfall is considered for three station i.e. Khudibazar station, Kunchha station and Gharedhunga station while $15 \mathrm{~mm}$ threshold for two station i.e. Manang Bhot station and Chame station. Rainfall threshold of $15 \mathrm{~mm}$ is taken for Chame and Manang Bhot station as they fall under rain shadow region of Nepal.

The result suggested the increase in frequency of intense rainfall (1.67 days/year) while decrease in the number of days with rain (-16.79 days/ year) for all station average. In all the station the number of days with rain is shortening while the frequency of intense rainfall is inclining except 

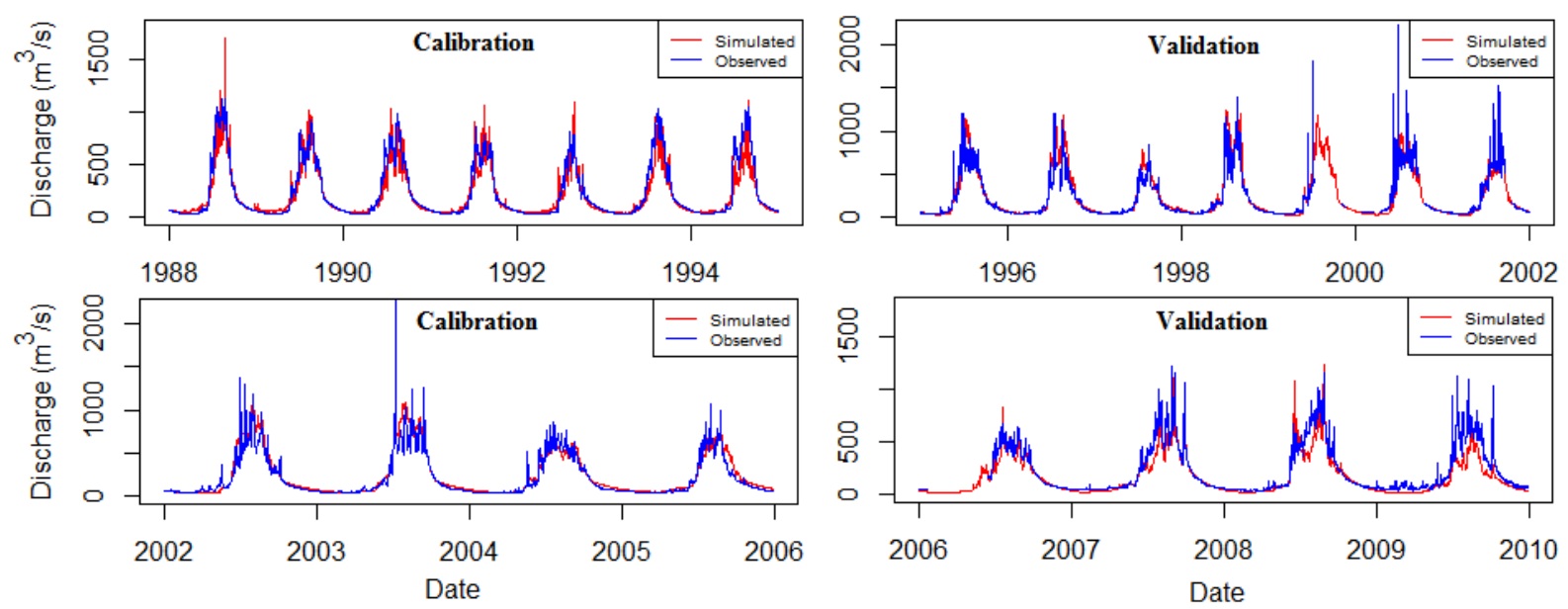

Figure 7: Time series of observed and simulated discharge using hydrological model for Marshyangdi River basin.

Table 1: Parameters used in calibration of HBV model

\begin{tabular}{|c|c|c|c|c|}
\hline \multirow[b]{2}{*}{ Parameters } & \multicolumn{2}{|c|}{ First Calibration } & \multicolumn{2}{|c|}{ Second Calibration } \\
\hline & $\begin{array}{c}\text { Vegetation } \\
\text { Zone } 1\end{array}$ & $\begin{array}{c}\text { Vegetation } \\
\text { Zone } 2\end{array}$ & $\begin{array}{c}\text { Vegetation } \\
\text { Zone 1 }\end{array}$ & $\begin{array}{c}\text { Vegetation } \\
\text { Zone } 2\end{array}$ \\
\hline \multicolumn{5}{|l|}{ Snow Routine } \\
\hline$\overline{\mathrm{TT}}$ & 2.5 & 2.5 & 2.5 & 2.5 \\
\hline CFMAX & 2 & 8 & 2 & 7.5 \\
\hline SFCF & 0.001 & 0.001 & 0.001 & 0.001 \\
\hline CFR & 0.05 & 0.05 & 0.05 & 0.05 \\
\hline CWH & 0.019 & 0.02 & 0.019 & 0.02 \\
\hline CFGlacier & 0 & 1 & 0 & 1 \\
\hline CFSlope & 0.89 & 0.89 & 0.89 & 0.89 \\
\hline \multicolumn{5}{|c|}{ Soil Moisture Routine } \\
\hline FC & 440 & 400 & 440 & 400 \\
\hline LP & 0.54 & 0.54 & 0.54 & 0.54 \\
\hline BETA & 0.6 & 0.7 & 0.6 & 0.7 \\
\hline \multicolumn{5}{|l|}{ Response Routine } \\
\hline PERC & 3.5 & & 3.5 & \\
\hline UZL & 6 & & 3 & \\
\hline K0 & 0.088 & & 0.096 & \\
\hline K1 & 0.049 & & 0.072 & \\
\hline $\mathrm{K} 2$ & 0.008 & & 0.009 & \\
\hline \multicolumn{5}{|l|}{ Routing Routine } \\
\hline MAXBAS & 1 & & 1 & \\
\hline \multicolumn{5}{|l|}{ Other Routine } \\
\hline$\overline{\text { Cet }}$ & 0.69 & & 0.036 & \\
\hline \multicolumn{5}{|c|}{ Catchment Parameter } \\
\hline PCALT & 6 & & 6 & \\
\hline TCALT & 0.6 & & 0.6 & \\
\hline PELEV & 1779.6 & & 1779.6 & \\
\hline TELEV & 1780 & & 1780 & \\
\hline
\end{tabular}


Table 2: Efficiency of Model using HBV hydrological model for Marshyangdi basin (1988-2009)

\begin{tabular}{|l|c|c|}
\hline Efficiency & First Calibration & Second Calibration \\
\hline $\mathrm{R}^{2}$ & 0.8795 & 0.8158 \\
Efficiency of Model & 0.8604 & 0.8061 \\
Efficiency using ln(Q) & 0.8746 & 0.9086 \\
Mean Difference (mm/year) & -25 & 12 \\
Efficiency Seasonal & 0.8604 & 0.8061 \\
Efficiency Weighted & 0.8802 & 0.76 \\
Peak Goodness & -0.3524 & 0.101 \\
\hline
\end{tabular}

for the Manang Bhot station i.e. -0.142 days/ year decrease in frequency of intense rainfall and decrease by -33.21 days/year in number of rainy days as the analysis suggested the decline in rainfall amount there. The frequency of the intense rainfall affects the river discharge and also can induce extreme events like flood and landslide hazard and future projection suggested the increase in precipitation which clearly state the future impact on basin due to changing climate.

There is very little bias between the observed and simulated discharge for most of the time except for some sharp peaks as well as some low flow event. Overall, the model simulated good result and able to capture peaks and low flow. The efficiency Table (2) clearly interprets ability of model to simulate hydrological characteristic within basin.

The simulated discharge generated excellent result for Marshyangdi basin with efficiency more than 0.80 for different efficiency tests. The coefficient of determinant $\mathrm{R}^{2}$ value $(0.88$ for fist calibration and 0.82 for second calibration) and very low value of peak goodness represent the ability of model to simulate the seasonal changes in the river discharge.
In order to test the goodness of fit the NashSutcliffe Efficiency (NSE) and the volume difference (VD) (Figure 8) between the observed and simulated discharge is carried out. The 0.80 NSE and the total volume difference of $1.43 \%$ suggest the simulated discharge fits with the observed discharge and future prediction based on the calibrated parameters can be used.

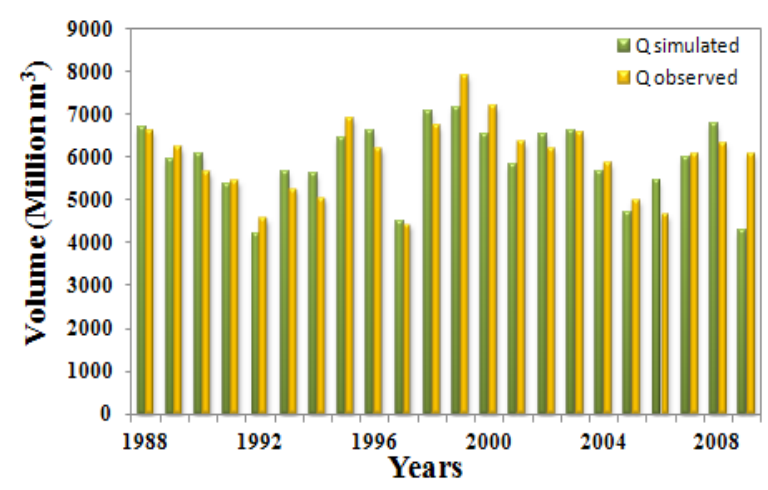

Figure 8: Yearly volume difference between simulated and observed discharge.

In order to examine the rainwater contribution to river statistical analysis i.e. correlation coefficient analysis is carried out between average rainfall and average river discharge of the Marshyangdi basin from year 1988 to 2009 by using Pearson's coefficient and is calculated as 0.6912 which was statistically significant at $\mathrm{N}=22, \mathrm{p}=0.01$ as shown in Figure (11). 


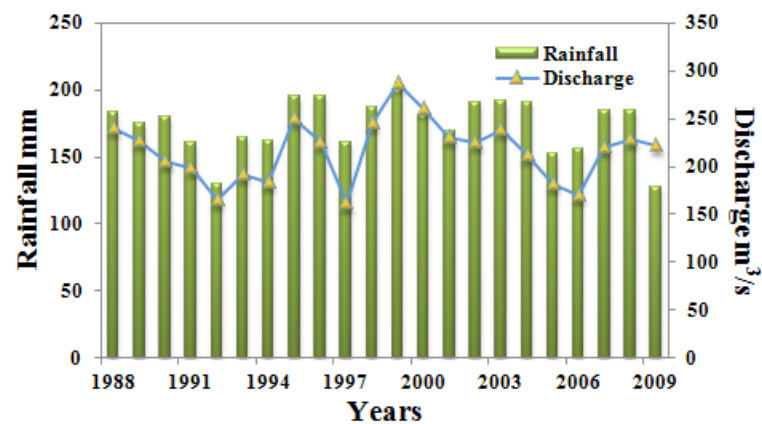

Figure 9: Statistical Relation between rainfall and discharge within the study area.

Around $70 \%$ of the total water discharge flowing through Marshyangdi is depended on the rainfall which suggested that change in rainfall pattern have definite effect on stream flow. The future rainfall data i.e. 2030-2050 based on DHM data portal using the A1B scenario suggested the increase in precipitation within study area. The statistical downscaled product as well as the DHM portal dataset predicted incline in rainfall (Figure 10).

Although there is certain level of uncertainty in the model simulated product, the future rainfall

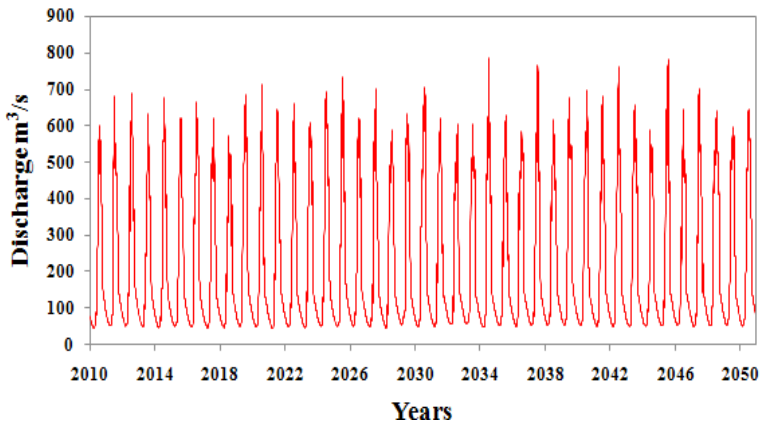

Figure 11: Time series of projected discharge from 20102050 for Marshyangdi Basin.

predicted by these model suggests increasing rainfall pattern over study area. Even, the present data from 1988-2009 suggest the increase in frequency of intense rain while decrease in number of rainy days. The increasing rainfall would definitely have adverse impact in future water discharge from Marshyangdi basin as rainfall dependency on river discharge for this basin is very high.

The hydrological model simulated the future discharge which derive more or less similar discharge from 2010-2050. Since, there is huge
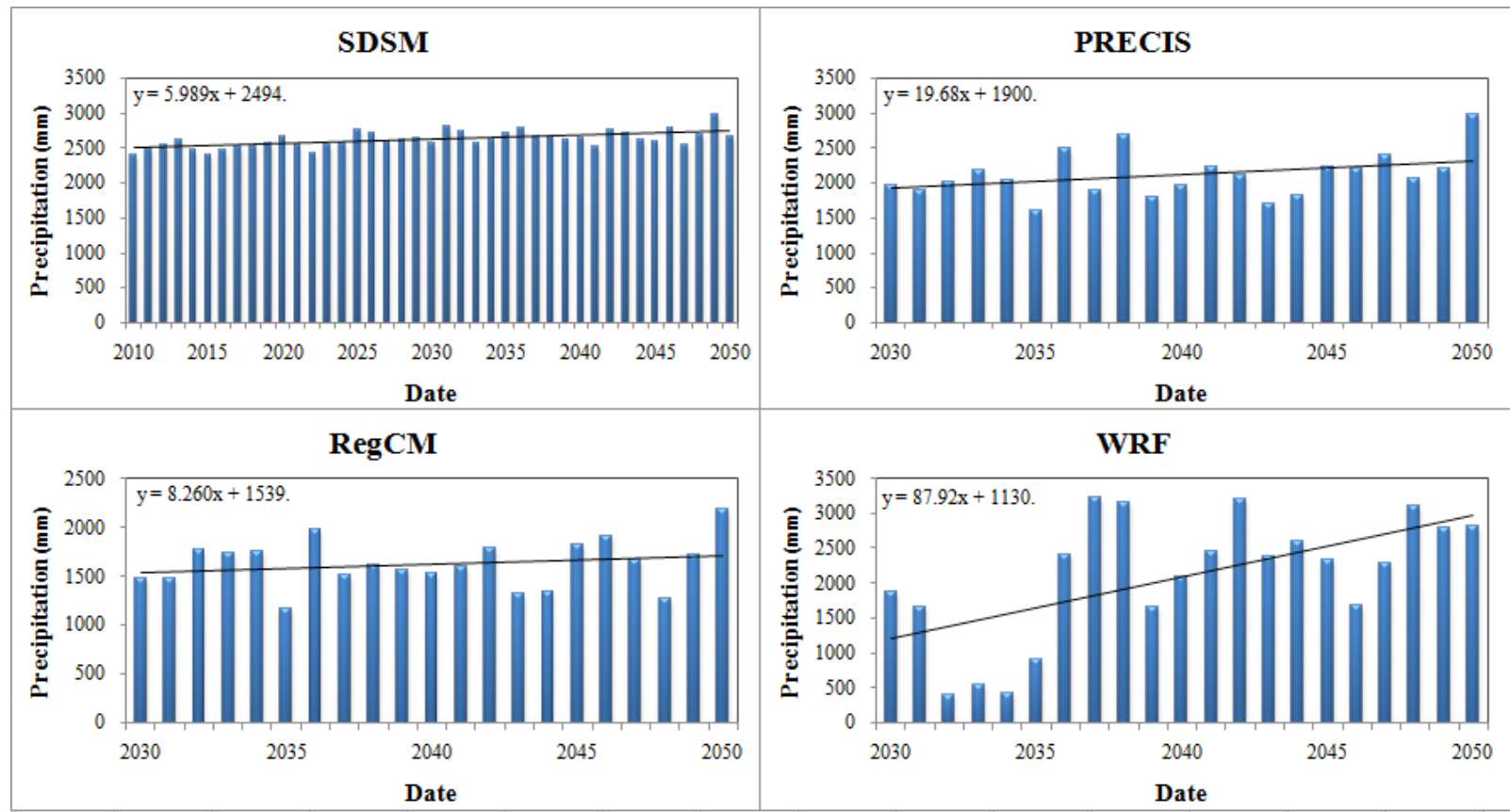

Figure 10: Rainfall projection using different downscaling methods. 
dependency of discharge with rainfall in this basin thus slight change is observed in this basin. Marshyangdi basin is also glacierized basin so there is influence of glacier melt in discharge. The climate change significantly has an effect on glacier melt they are very sensitive to the rising temperature and precipitation. The change in area of glacier since 1990-2000 deviated from landsat image (Bajracharya et al., 2014) clearly shows the change going on within study area (Table 3).

\section{Table 3: Change in Glacier based on ICIMOD decadal change study}

\begin{tabular}{|ccc|}
\hline Year & Area $\left(\mathbf{K m}^{2}\right)$ & Area Change $\left(\mathbf{K m}^{2}\right)$ \\
\hline 1990 & 555.9 & 0.0 \\
2000 & 534.7 & 21.3 \\
2010 & 508.3 & 26.4 \\
\hline
\end{tabular}

From year 1990 to 2010 there is area change of $47.7 \mathrm{~km} 2$ of glacier within the study basin and if the projected temperature and precipitation change occurs, more glaciers will be lost and significant impact would occur downstream as a result of climate change. The risk associated to glaciated system with connection to climate change is also the formation of Glacier Lake and their outburst. Several studies related to Thulagi Glacier within this basin has been made by several institution and researcher which reveled the gradual increase of lake from $0.22 \mathrm{~km} 2$ to $0.76 \mathrm{~km} 2$ comparing map of 1958 and 1992 (Ghimire, 2005) but another study carried by Department of Hydrology and Meteorology (DHM, 1997) suggests less danger because it is dammed by extended ice bodies which require period of hundred years. The formation of Glacier Lake itself can create massive hazard due to sudden glacier lake outburst flood as these event might be triggered by sudden avalanche and earthquake.

\section{CONCLUSION}

This study presents the impact of climate change on water resource based on available data and predicts the future impact based on the hydrological model simulation coupling the downscaling model. In this study the available hydro-meteorological data is used for analysis of present context and simulated the hydrological model which incorporates the glacier reservoir. The hydrological model is able to capture the changes except for some extremes and efficiently predicted the adverse effect on water resources due to change in the meteorological variables based the scenario. The use of hydrological model coupled with the downscaling method is appropriate for Himalayan region but physically based hydrological coupled with dynamical downscaling techniques would be beneficial in future.

\section{ACKNOWLEDGEMENTS}

This study was carried out by fund granted from UNESCO-IHP New Delhi, which administered by The SmallEarth Nepal. The daily temperature, rainfall and river discharge data is provided by Department of Hydrology and Meteorology (DHM), glacier data is made available from ICIMOD. Thus, we would like to acknowledge these institutions for helping us carry out this research. We would like to acknowledge Dr. Laxmi Prasad Devkota for providing valueable support and information of Marshyangdi basin through Nepal Development Research Institute (NDRI). We would like to acknowledge Dr. Jan Seibert (University of Zurich) for providing license for HBV light model. 


\section{REFERENCES}

Akhtar, M., Ahmad, N., \& Booij M. J., 2008. The impact of climate change on water resources of Hindukush-Karakorum-Himalaya region under different glacier coverage scenario. Journal of Hydrology 355, $148-163$.

Alam, M. and Regmi, B.R., 2004. Adverse Impacts of Climate Change on Development of Nepal: Integrating Adaptation into Policies and Activities. Bangladesh Centre for Advance Studies (BCAS). Working paper 3.

Bajracharya, S. R., Maharjan, S. B., Shrestha, F., Bajracharya, O. R., Baidya, S., 2014, Glacier status in Nepal \& dedacal change from 1980 to 2010 based on landsat data, Kathmandu: ICIMOD.

Bergström, S. 1992. The HBV model: Its structure and applications. Swedish Meteorological and Hydrological Institute. Uppsala University, Sweden.

Beven, K. \& Binley, A., 1992. The future of distributed models: model calibration and uncertainty prediction. Hydrological Processes 6, 279-298.

Bolch, T., Kulkarni, A., Kääb, A., Huggel, C., Paul, F., Cogley, J. G., Frey, H., Kargel, J. S., Fujita, K., Scheel, M., Bajracharya, S., \& Stoffel, M., 2012. The state and fate of Himalayan glaciers. Science 336(6079), 310-314.

Chun, K. P., 2010. "Statistical Downscaling of Climate Model Outputs for Hydrological Extremes By". Imperial College London. doi:10.1029/2009RG000314.

DHM, 1997. Thulagi Glacier Lake Study. (Final report), Department of Hydrology and Meteorology (DHM), His Majesty's Government of Nepal, in cooperation with Federal Institute for Geo-sciences and Natural Resource (BGR), Hannover, Germany.

Duan, Q., Sorooshian, S. \& Gupta, V.K., 1992. Effective and efficient global optimization for conceptual rainfall-runoff models. Water Resource Research 28(4), 1015-1031.

Fujita, K., Nakawo, M., Fugi, Y. \& Paudyal, P., 1998. Change in Glacier in Hidden Valley, Mukut Himal, Nepal Himalayas from 19741994, Journal of Glaciology 43, (143), 583588.

Ghimire, M., 2005. Review of Studies on Glacier Lake Outburst Floods and Associated Vulnerability in the Himalayas. Himalayan Review. 35, 49-64.

Grotch, S.L., and MacCracken, M.C., 1991. The Use of General Circulation Models to Predict Regional Climatic Change. Journal of Climate 4, 286-303.

Hagg, W., Mayer, C., Lambrecht, A., \& Helm, A., 2008. Sub-debris melt on Southern Inylchek glacier, central Tien Shan. Geografiska Annaler 90, 55-63.

Hisdal, H., Kerstin St, Lena M. T. and Siegfried Demuth, 2006. Have streamflow droughts in Europe become more severe or frequent? International Journal of Climatology 21, 317-333.

Horton, P., Schaefli, B., Mezghani, A., Hingray, B., \& Musy, A.,2006. Assessment of climate-change impacts on alpine discharge regimes with climate model uncertainty. Hydrological Processes 20(10), 2091-2109.

Immerzeel, W. W., Van Beek, L. P., \& Bierkens, M. F. 2010. Climate change will affect the Asian water towers. Science 328(5984), 1382-1385. 
Jansson, P., Hock, R., and Schneider, T., 2003. The concept of glacier storage: a review. Journal of Hydrology 282(1), 116-129.

Jakeman, A.J. and Hornberger, G.M., 1993. How much complexity is warranted in a rainfallrunoff model? Water Resource Research vol.29(8), 2637-2649.

Kayastha, R.B., Ageta, Y., and Nakawo, M., 2000. Positive degree-day factors for ablation on glaciers in the Nepalese Himalayas: case study on Glacier AXOIO in Shorong Himal, Nepal. Bulletin of glacier research 17, 1-10.

Kripalani, R. H., and Kulkarni, A. 1997. Climatic impact of El Nino/La Nina on the Indian monsoon: A new perspective. Weather 52(2), $39-46$.

Meehl, G.A., 1994. Influence of the Land surface in Asian Summer Monsoon: External Condition Versus Internal Feedback. Journal of Climate 7, 1033-1047.

Mingjie, G., Tianding, H., Baisheng, Y., \& Keqin, J., 2013. Characteristics of melt water discharge in the Glacier No. 1 basin, headwater of Urumqi River. Journal of Hydrology 489, 180-188.

Modarres, R. and Quarda, T.B.M.J., 2013. Modeling rainfall-runoff relationship using multivariate GARCH model. Journal of Hydrology 499, 1-18.

MoEST, 2010. Nepal Capacity Self-Assessment for Global Environment Management, Nepal Thematic Assessment Report: Climate Change, Government of Nepal, Ministry of Environment Science and Technology, Singadurbar, Kathmandu, Nepal.

Nash, J. E. \& Sutcliffe, J. V., 1970. River flow forecasting through conceptual models, part 1-a discussion of principles. Journal of Hydrology 10(3) 282-290.
Pachauria, R.K., 1992. Global warming impacts and implications for South Asia. In: The regions warming: impacts and response strategies [Schmandt, J. \& Clarkson (eds.)], Oxford University Press, New York, 79-90.

Rupa Kumar K., Sahai A.K., Krishna Kumar K., Patwardhan S.K., Mishra P.K., Revadekar .JV., Kamala K., Pant G.B., 2006. High resolution climate change scenario for India for the 21st century. Current ScienceBangalore 90(3), 334-345.

Seibert, J., 1997. Estimation of Parameter Uncertainty in the HBV Model. Earth 28(1982), 247-262.

Seibert, J., 2000. Multi-cirteria Calibration of a Conceptual Runoff Model Using a Genetic Algorithm. Hydrology and Earth System Sciences 4 (2): 215-224.

Seibert, J., 2005. HBV light version 2, User's manual. Department of Physical Geography and Quaternary Geology, Stockholm University.

Seibert, J. and Beven, K.J., 2009. Gauging the ungauged basin: how many discharge measurements are needed? Hydrology and Earth System Sciences 883-892.

Sharma, K.P., Moore III \& Vorosmarty, C.J., 2000a. Anthropogenic, Climatic and Hydrological Trends in the Koshi Basin, Himalaya, Climate Change 47, Kluwer Academic Publisher, Dordrecht, the Netherland, 157.

Sharma, R.H. and Shakya, N.M., 2006. Hydrological changes and its impact on water resources of Bagmati watershed, Nepal. Journal of Hydrology 327(3-4), 315-322.

Shrestha, A. B., and Aryal, R., 2010. Climate change in Nepal and its impact on Himalayan glaciers. Regional Environmental Change 11(S1), 65-77. 
Shrestha, A. B., Wake, C. P., Mayewski, P. a., and Dibb, J. E., 1999. Maximum Temperature Trends in the Himalaya and Its Vicinity: An Analysis Based on Temperature Records from Nepal for the Period 1971-94. Journal of Climate 12(9), 2775-2786.

Sivapalan, M., Takeuchi, K., Franks, S. W., Gupta, V. K., Karambiri, H., Lakshmi, V, Liang, X., McDonnell, J. J., Mendiondo, E., O, Connell, Oki, T., Pomeroy, J. W., Schertzer, D., Uhlenbrook, S., \& Zehe, E., 2003. IAHS Decade on Predictions in Ungauged Basins (PUB), 2003-2012: Shaping an exciting future for the hydrological sciences. Hydrological Sciences Journal 48(6), 857880.
Sperna Weiland, F. C., Tisseuil, C., Dürr, H. H., Vrac, M., \& Van Beek, L. P. H., 2012. Selecting the optimal method to calculate daily global reference potential evaporation from CFSR reanalysis data for application in a hydrological model study. Hydrology and Earth System Sciences 16, 983-1000.

Wilby, R.L., and Dawson, C., 2007. User Manual SDSM 4.2 - A decision support tool for the assessment of regional climate change impacts.

Yamada, T., Shiraiwa, T., Iida, H., Kadota, T., Watanabe, T., Rana, B., Ageta, Y., Fushimi, H., 1992. Fluctuation of the glaciers from 1970's to 1989 in the Khumbu, Shorong and Langtang regions, Nepal Himalayas. Bulletin of glacier research 10, 11-19. 